\title{
Do Human Resources Run Economic Growth? Empirical Evidence from Pakistan
}

\author{
Bilal Alam ${ }^{\text {a }}$, Muhammad Niamat Ullah ${ }^{\text {b }}$ \\ ${ }^{a}$ Department of Economics, Institute of Social Sciences,Gomal University Dera Ismail Khan, Pakistan \\ Email: bilal.alam868@gmail.com \\ ${ }^{\mathrm{b}}$ Department of Economics, Institute of Social Sciences, Gomal University Dera Ismail Khan, Pakistan \\ Email: nematbabar@gu.edu.pk
}

\begin{tabular}{ll}
\hline ARTICLE DETAILS & ABSTRACT \\
\hline History: & This study analyzes the role of human capital in economic growth using \\
Accepted 30 April 2021 & data from 1981 to 2017. The data were taken from the World Bank \\
Available Online June 2021 & (WDI) and the Economic Survey of Pakistan (Various Issues). It was \\
& scrutinized for stationarity of variables through ADF and an appropriate \\
Keywords: & time series econometric technique of ARDL is applied for empirical \\
Education Index; Health Index; & $\begin{array}{l}\text { analysis. The results suggest that both proxies of human capital, } \\
\text { Human Capital }\end{array}$ \\
& $\begin{array}{l}\text { education, and health have positive impacts on the economic } \\
\text { development of Pakistan. The study findings also suggest that }\end{array}$ \\
JEL Classification: & government machinery may divert enough resources for the \\
P36, I18, J24 & capital for achieving the desired goal of higher growth and development.
\end{tabular}

DOI: $10.47067 /$ reads.v7i2.351

(C) 2021 The authors. Published by SPCRD Global Publishing. This is an open access article under the Creative Commons AttributionNonCommercial 4.0

Corresponding author's email address: bilal.alam868@gmail.com

\section{Introduction}

Human Capital (HC) is a wider concept (Goode 1959, Mincer 1958, Becker 1961 and Schultz 1961) which has all the indispensable ingredients of society, culture, politics, and economics (Harbison and Myers, 1964). For economists, it is an important determinant of growth. The various theoretical discussion has been made on the possible role of human capital in economic growth e.g. growth theories human capital. Two main theories highlighted the role of human capital in economic growth i.e. exogenous theory of Solow (1956) and the Endogenous Theory of Romer (1989, 1990, \& 1994) and Lucas (1988). In exogenous growth theory, technology is taken as an exogenous factor and the role of labor and capital is defined in this framework while Endogenous theories of growth postulated that human and physical capitals are the prime factors of growth. Various researchers confirm the role of human capital in the development and growth of a country (Sequeira 2007; Wilson \& Briscoe 2004; Abbas 2000). 


\section{Review of Economics and Development Studies, Vol. 7 (2) 2021, 205-213}

Most of the empirical studies used education and health as a proxy of human capital in their studies and claimed that it is the real proxy that captures the true picture of human capital. Both developed and developing countries spend a handsome amount of their budget on health and education with a belief that good health and a well-educated labor force are more productive than ill-health and less educated ones. For developing countries, it is a bit difficult to cope with the challenges of education and health for all slogans. It is observed that in less developed nations wealthier people enjoy good health and education facilities compared to poor masses of the country that's why both the drop out and mortality rates are higher than the developed world e.g. North American, European and Japanese children have the capability of getting 12 years of education (on average) as compared to the African or South Asian countries who spend less than 4 years in school (UNDP 1998).

Since the inception of Pakistan, the government paved great attention to developing human capital. Zulfiqar Ali Bhutto government put extra efforts to enhance education through nationalization policy along with improving the manpower in Pakistan by sending it to develop world specifically Golf countries. In the current scenario, Pakistan ranked $164^{\text {th }}$ (in a total of 195 countries) in respect of investment in health and education, the two very important determinants of human capital. The position of Pakistan was improved from 166 to 164 from 1990 to 2016 . These statistics suggest that we are very lag behind the developed world as far as human capital development is concerned. To achieve higher economic benefits we need to develop our human capital and this study is a timely struggle to evaluate the role of human capital in the economic development of Pakistan.

The rest of the paper is organized as follows; after the brief introduction, there is a discussion on relevant literature which is followed by data and methods. Results and discussion are carried after a methodology. The conclusion is presented in the last section of this study.

\section{Literature Review}

Although there is a huge discussion on the role of human capital in economic growth but to make the discussion easy and to come out with some conclusion, the current study emphasized the most relevant studies.

Ali et al (2016) examined the role of human capital in Bangladesh's economy for the sample period from 1981 to 2014. By applying Johansen Cointegration they found that the accumulation of human capital has a significant and positive effect on Bangladesh's economy. Khan et al. (2016) analyzed the selected South Asian countries i.e. Srilanka, Pakistan, Bangladesh, and India. In the time frame of 1971 to 2013, they found that human capital (which was proxy by education and health) boost the growth of these sample countries.

Guptha et al (2017) also analyzed the same hypothesis for the Indian economy taking 1991 to 2105 as a sample period of the study. Study results specify that both human capital and technology have a positive and significant impact on India's economic growth. Hassan (2017) examined male and female health capital's effect on economic growth. Study findings showed that in the long run, both variables have a significant and positive effect on the nation's growth on the other hand both the variables have a negative and insignificant impact on the growth process.

Hakooma and Seshamani (2017) investigated the underlying hypothesis for the Zambian economy. They found that there are long-run influence of human capital on the economic development of Zambia. 


\section{Review of Economics and Development Studies, Vol. 7 (2) 2021, 205-213}

Osoba and Tella (2017) examined interactive effect between economic development and human capital accumulation in Nigeria. They have taken education and health spending variables as independent variables whilst GDP has taken as a dependent variable. To examine the data fully modified ordinary least square has been applied to calculate the findings. Study results specify that on both sides of dependent and independent the variables have a positive and significant relationship and also indicate interactive effect between education and health variables.

Ogundari and Awokuse (2018) suggested that health and education have been normally applied to estimate Human Capital and similarly vast literature has been estimated the relationship between Human Capital and the growth process. Thus both education and health capital are being considered the major elements for the formation of Human Capital and it is the human capital that contributes very much to enhance the economic growth of any country.

Khan and Chaudhry (2019) estimated that the formation of human capital plays a critical role in enhancing economic growth and create employment for individuals in any nation. A fundamental objective of the literature is to calculate the impact of human capital on economic growth and employment in developing countries. For this purpose life expectancy and education are taken as proxies for Human Capital by utilizing panel data ranging from 1996 to 2018. Results of this analysis found out that life expectancy and education have a positive and significant effect on real GDP and employment in developing countries.

Maku et al (2019) checked the impact of human capital accumulation on Nigerian economy's using ARDL to estimate the short-run and long-run impact of HC on the selected country's economic growth. This analysis found that in the short run human capital and economic growth have a negative and insignificant relationship while in the long run it is found the presence of a significant and positive relationship between the two in the case of Nigeria.

It is concluded from the mentioned literature that health and education are the major elements for improving the individual's life. For any technological development, education performs a critical role it is experienced that those countries have made progress in technology that could be able to improve their education. Similarly, technological development makes capable the labor force to raise their productivity level and it raises their remuneration. Higher-income individuals make them capable to improve their health status. It is a natural fact that healthy individuals are more efficient and active as compare to under nourish they proved themselves very productive for their country's economic development. The main aim of this analysis is to check the impact of human capital in terms of male education and male health on the economic performance of Pakistan's economy using the time series data from 1981 to 2017.

\section{Materials and Methods}

\subsection{Model Specification}

Previous empirical literature used various models to analyze the role of human capital in economic growth. This study followed Knowles and Owen (1995) who augmented the Mankiew et al. (1992) growth, model. The specific form of the model is;

$$
\begin{array}{ll}
G D P=f(M E D U, M L F, F C F, M L E) & -------3.1 \\
G D P=f(M E D U, M L F, F C F, M L E) & --------3.1
\end{array}
$$


Review of Economics and Development Studies, Vol. 7 (2) 2021, 205-213

Here in this model, growth is represented by gross domestic product, MEDU is used for male education which is one of the proxies of human capital, MLF is male labor force, FCF is fixed capital formation and MLE is male life expectancy. The specific econometric form of the model is as following;

$$
\ln G D P t=\alpha+\beta 1 t M E D U t+\beta 3 \mathrm{MLFt}+\beta 2 F C F t+\beta 4 M L E t+\varepsilon t-------------3.2
$$

Here $\varepsilon \alpha$ and $\beta$ are the error term, constant term and slope coefficient respectively and "t" is time subscript.

\subsection{Data Sources}

\subsubsection{Data}

Secondary data for the period of 1981 to 2017 are collected from World Development Indicators and different issues of Pakistan Economic Surveys. Where Gross Domestic Product (GDP) is employed to calculate economic growth. Earlier empirical literature used the same proxy for economic growth (i.e. Khan 2016; Chaudhry 2009). Male education is calculated by using the education enrollment index. Its calculation is based on the various stages of schooling levels. The level of education as a proxy of human capital was also used by previous literature (e.g. Barro \& Lee; 2000). Physical Capital is a proxy by FCF which is also used by Ali et al (2012). Male labor force participation is another important determinant of human capital which one of the most productive means especially in developing nations. Following Knowles and Owen (1995) this study used the male life expectancy index as a proxy of human capital. Literature supports the idea that healthy individuals have a positive and significant influence on any economic growth as healthy people having higher prospect to acquire higher education, training \& skills which in turn make them capable to work for a longer time to increase their productivity.

\subsubsection{Estimation Strategy}

This study used the ARDL approach for model estimation developed by Pesaran and Shin (1995; 1998 and 2001) This approach is completed in three different stages where at stage one it is attempted to find out the cointegration in the model, while in the second and third phase (once the cointegration established) long and short-run elasticities are calculated. Short Run deviations were estimated through Error Correction Mechanism (ECM) suggested by Sargan (1964). Some diagnostic tests were also employed to find the validity of the model. The coefficient stability was tested through CUSUM and CUSUMQ.

\section{Results and Discussion}

\subsection{Unit Root Analysis}

The stationarity of data is tested through the application of the ADF test. Although testing data for stationarity is not the pre-condition of ARDL but still, it is believed that time-series data most of the time has time trends and which may cause spuriousness in results if not handled properly (Gujrati; 2003) therefore this study tested the data for stationarity to avoid the misleading conclusion. Results of stationarity analysis are given in table 4.1.

Table: 4.1 Unit Root test

\begin{tabular}{|l|l|l|l|l|l|}
\hline \multirow{2}{*}{ Variable } & Level & \multicolumn{2}{l|}{$1^{\text {st }}$ Difference } & Decision \\
\cline { 2 - 6 } & $\mathrm{C}$ & $\mathrm{T}+\mathrm{C}$ & $\mathrm{C}$ & $\mathrm{T}+\mathrm{C}$ & \\
\hline LnGDP & $-2.25(0.191)$ & $-2.67(0.253)$ & $-3.46(0.015)$ & $-3.50(0.054)$ & $\mathrm{I}(1)$ \\
\hline Medu & $0.11(0.962)$ & $-2.71(0.237)$ & $-5.63(0.000)$ & $-5.58(0.000)$ & $\mathrm{I}(1)$ \\
\hline MLF & $-5.86(0.000)$ & $-6.07(0.000)$ & - & - & $\mathrm{I}(\mathrm{o})$ \\
\hline FCF & $-4.37(0.001)$ & $-4.34(0.007)$ & - & - & $\mathrm{I}(\mathrm{o})$ \\
\hline LEM & $-1.82(0.723)$ & $-1.87(0.648)$ & $-5.84(0.000)$ & $-5.95(0.000)$ & $\mathrm{I}(1)$ \\
\hline
\end{tabular}


Review of Economics and Development Studies, Vol. 7 (2) 2021, 205-213

Results of stationarity analysis suggested that variables like Male labor Force and Fixed Capital Formation are stationary at a level while others at first difference. Having a mixed order of integration leads us to apply the ARDL approach discussed above.

\subsection{Long Run Cointegration}

The result of long-run cointegration is made based on Wald F statistics. Is suggested by Pesaran and Shin $(1995,1998,2001)$ that for the presence of long-run cointegration the calculated Wald $F$ value has to be greater than the upper boundaries of tabulated Wald $\mathrm{F}$ values at $5 \%$ level. Results are displayed in table 4.2 which suggested that there is long-run cointegration in the model as the calculated value (6.537) is far upper than the upper boundaries of tabulated values (4.544) at 5\% level.

\section{Table 4.2: The Bound Test for Cointegration}

\begin{tabular}{|l|l|l|l|l|}
\hline Specification & $\begin{array}{l}\text { Lower } \\
\text { bound }\end{array}$ & $\begin{array}{l}\text { Upper } \\
\text { bound }\end{array}$ & F-statistic & Decision \\
\hline $\begin{array}{l}\text { LNGDP/MEDU, FCF, } \\
\text { MLF, LEM }\end{array}$ & 3.202 & 4.544 & $6.537(.031)$ & Integrated \\
\hline
\end{tabular}

\subsection{Long Run Estimates}

Here in this model, it is confirmed the presence of Long Run Cointegration and we proceed towards estimating the LR calculations. In table 4.3 indicate that all the chosen variables' coefficients are positive and significant. In our calculation, it is found that an increase of one percent in the life expectancy of the male population leads to a seventeen percent increase in economic growth. The outcomes bear with the suggestion of Knowles and Owen (1995) and Barro \& Martin (1995) having discovered a viable and positive relationship between male Life Expectancy and income level of any nation. The findings of our study imply that healthy individual's contribution to economic productivity is higher than unhealthy individuals which leads to raising economic growth.

Similarly, results also show that contribution of male education to economic growth is positive and significant. Study outcomes suggest that a $1 \%$ increase in male education raises economic growth by fifteen percent and these results are consistent with well-known Barro \& Lee (1994) \& Barro \& Martin (1995). The reason behind education's positive impact on the economy is that educations generate a skilled and trained labor force and this type of labor force has a much higher productivity level as compared to un-skill and untrained individuals. Our model findings come to this conclusion that by raising the training and skill of the individuals the output per worker is rising and in turn, it leads to higher economic growth. It is normally believed that the formation of human capital perform a crucial role in shaping a country's economic growth. So it is concluded from this discussion through education and quality health facilities human capital of any nation may improve.

In our model, Fixed Capital Formation and Labor Force Participation are controlled variables that indicate positive and significant association with growth rate. The results displayed in Table 4.2 shows that every 1pc increase in FCF enhances GDP by 16 percent. Khan (2016) \& Lucas (1988) also found similar results and argued that if sufficient resources are redirected for improvement of human capital resultantly fixed capital would be utilized efficiently. It is the human capital that creates trained and skilled labor force and FCF efficient utilization required skill and train labor force. Further, the results also revealed that a 1pc increase in MLF leads to a 10pc rise in GDP which supports the idea of Khan (2016). In Pakistan male population having dominancy over the female population and due to this reason the greater part of the employed Labor Force compose of on Male Labor Force and their 
Review of Economics and Development Studies, Vol. 7 (2) 2021, 205-213

contribution to economic growth is significant. since workers work and earn income against providing their services by this way they save a part of their income for further investment to raise the productivity level of a nation.

Table.4.3 Long Run Coefficients

\begin{tabular}{|l|l|l|l|l|}
\hline Regressor & Coefficient & Stand. Errors & T-Ratio & Prob \\
\hline LEM & .1760 & .0742 & 2.368 & {$[0.054]$} \\
\hline MLF & .1023 & .0436 & 2.346 & {$[.015]$} \\
\hline MEDU & .1586 & .0628 & 2.525 & {$[.050]$} \\
\hline FCF & .1626 & .0798 & 2.037 & {$[.046]$} \\
\hline A & 10.5506 & .054801 & 192.5261 & {$[.000]$} \\
\hline T & .010956 & .0065252 & 1.6790 & {$[.104]$} \\
\hline R-Squared .92 & & & \\
\hline R-Bar-Squared .88 & \multicolumn{5}{l|}{} \\
\hline F-stat. 54.8[.000] & & \\
\hline DW-statistic 1.9459 &
\end{tabular}

\subsection{Short Run Dynamics}

Short-run dynamics are not very much different than long-run elasticities. Error Correction Mechanism (ECM) suggests that any disequilibrium is adjusted with a reasonable speed of adjustment (41\%). Similarly, the values of R square and Adjusted $\mathrm{R}$ square show that variations in regress and are well explained by the regressors.

\section{Table.4.4 Short Run coefficients}

\begin{tabular}{|l|l|l|l|l|}
\hline Regressor & Coefficient & Stand. Errors & T-Ratio & Prob \\
\hline dLEM & .0740 & .0499 & 1.478 & {$[.153]$} \\
\hline dMLF & .0886 & .0396 & 2.2373 & {$[.081]$} \\
\hline dMEDU & .053983 & .023830 & 2.264 & {$[.031]$} \\
\hline$d F C F$ & .0043165 & .0013888 & 3.1081 & {$[.004]$} \\
\hline$d A$ & 4.4264 & 1.3037 & 3.3951 & {$[.002]$} \\
\hline$t$ & .0045963 & .0022486 & 2.0440 & {$[.050]$} \\
\hline ecm $(-1)$ & -.41954 & .12361 & -3.3940 & {$[.002]$} \\
\hline
\end{tabular}

\subsection{Diagnostic Tests}

The outcomes of the Diagnostic test are shown in table 4.5 which suggested that the model is free of heteroskedasticity and autocorrelation. Similarly, the table also confirmed that error terms are normality distributed and the model is functionally well structured.

\section{Table 4.5: Diagnostic Tests}

\begin{tabular}{|l|lc|}
\hline Test Statistics & \multicolumn{2}{|l|}{ LM Version } \\
\hline Serial Correlation & 1.009 & {$[.315]$} \\
\hline Functional Form & .1346 & {$[.714]$} \\
\hline Normality & 2.113 & {$[.348]$} \\
\hline Heteroscedasticity & .01606 & {$[.899]$} \\
\hline
\end{tabular}




\section{6: Stability Test}

Coefficient stability is confirmed through CUSUM and CUSUMQ. The displayed figures suggested that the coefficient remains in the given range.
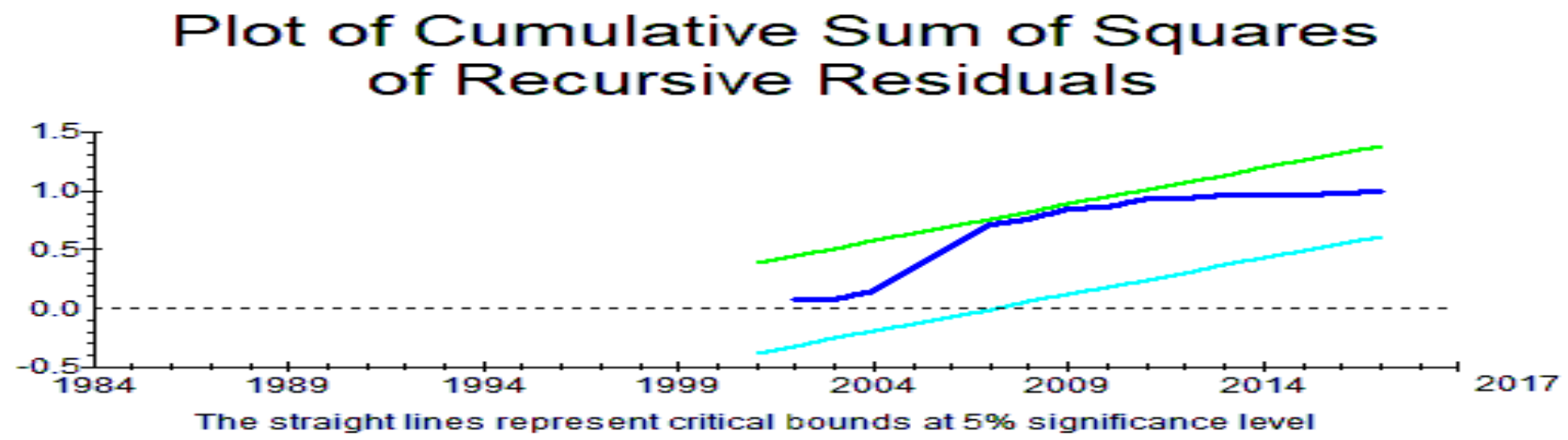

Figure 4.1: CUSUM

\section{Plot of Cumulative Sum of Recursive Residuals}

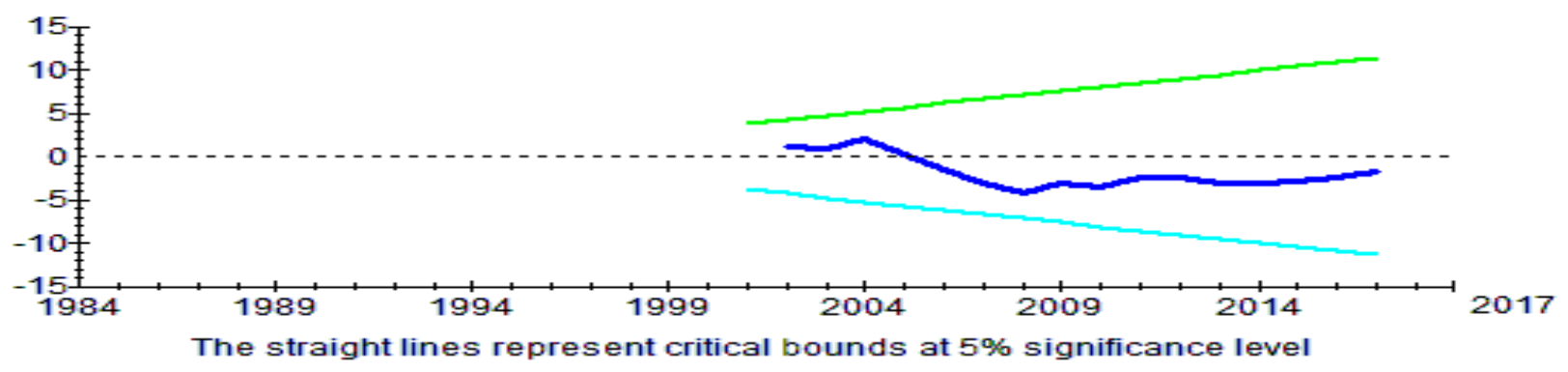

Figure 4.2: CUSUMQ

\section{Conclusion}

The possible role of human capital in the economic growth of Pakistan was investigated in this study. The data for this purpose was taken from Economic Surveys of Pakistan and World Development Indicators for the period from 1981 to 2017. The growth was measured through GDP and Human capital as a proxy by using male education and health indexes. The results revealed that human capital played a positive and significant role in the economic growth of Pakistan. The education and health sectors can play a pivotal role in generating inclusive economic growth rate for the long run on a sustained basis.

\section{References}

Abbas, Q. (2000). The role of human capital in economic growth: a comparative study of Pakistan and India. The Pakistan Development Review, 451-473.

Ali, S., Alam, K. J., \& Noor, M. T. (2016). An econometric analysis of human capital development and economic growth in Bangladesh. Journal of Economics and Sustainable Development, $7(17), 30-38$.

Barro, R. J. (1996). Health and economic growth. Mimeo, Cambridge: Harvard University.

Barro, R. J. \& Lee, J.W. (1994) Sources of economic growth. In: Carnegie-Rochester Conference Series on Public Policy, 40, 1-46. 


\section{Review of Economics and Development Studies, Vol. 7 (2) 2021, 205-213}

Barro, R. J., \& Martin, S. X. (1995). Economic growth. McGraw-Hill, New York.

Becker, G. S. (1960). Underinvestment in college education?. The American Economic Review, 50(2), 346-354.

Becker, G. S., Murphy, K. M., \& Tamura, R. (1990). Human capital, fertility, and economic growth. Journal of Political Economy, 98(5), 12-37.

Banerjee, A., Dolado, J., \& Mestre, R. (1998). Error-correction mechanism tests for cointegration in a single-equation framework. Journal of Time Series Analysis, 19(3), 267-283.

Bloom, D. E., Canning, D., \& Sevilla, J, (2004). The effect of health on economic growth: A production function approach. World Development, 32(1), 1-13.

Carmeli, A., \& Schaubroeck, J. (2005). How leveraging human resource capital with its competitive distinctiveness enhances the performance of commercial and public organizations. Human Resource Management, 44(4), 391-412.

Chaudhry, A. A. (2009). Total factor productivity growth in Pakistan: An analysis of the agricultural and manufacturing sectors. The Lahore Journal of Economics, 14, 1.

Engle, R. F., Lilien, D. M., \& Robins, R. P. (1987). Estimating time varying risk premia in the term structure: The ARCH-M model. Econometrica: Journal of the Econometric Society, 391-407.

Goode, R. B. (1959). Adding to the Stock of Physical and Human Capital. The American Economic Review, 49, 147-55.

Grossman, M. (1972). On the concept of health capital and the demand for health. J. Pol Econ. 80:223-255.

Gujarati, D. N. (2003). Basic econometrics. McGraw Hill, New York.

Guptha, S. K., Mallikarjuna, M., \& Rao, P. (2017). Human capital technology and economic growth in India: An ARDL approach. International Journal of Business Quantitative Economics and Applied Management Research, 3(9).

Hakooma, M. R., \& Seshamani, V. (2017). The impact of human capital development on economic growth in Zambia: an econometric analysis. International Journal of Economics, Commerce and Management (UK), Vol. V, Issue 4.

Hassan, G., Cooray, A., \& Holmes, M. (2017). The effect of female and male health on economic growth: Cross-country evidence within a production function framework. Empirical Economics, 52(2), 659-689.

Khan, J., Malik, Z. K., \& Arafat, Z. (2016). The impact of human capital on economic growth: Evidence from selected Asian countries. SUIT Journal of Social Sciences and Humanities, 1(1), 1-16.

Khan,J.,\& Chaudhry,I.S. (2019). Impact of human capital on employment and economic growth in developing countries. Review of Economics \& Development Studies, 5(3), 487-496.

Knowles, S., \& Owen, P. D. (1995). Health capital and cross-country variation in income per capita in the Mankiw-Romer-Weil model. Economics Letters, 48(1), 99-106.

Knowles, S., \& Owen, P. D. (1997). Education and health in an effective-labour empirical growth model. The Economic Record, 73(223), 314-328.

Lant, P. (1997). Where Has All the Education Gone? World Bank Policy Research Department Working Paper No. 1581 (revised), Washington DC.

Lucas Jr, R. E. (1988). On the mechanics of economic development. Journal of Monetary Economics, 22(1), 3-42.

Maku, O. E., Ajike, E. O., \& Chinedu, S. (2019). Human capital development and macro -economic performance in Nigeria: An autoregressive distributed lag (ARDL) Approach. Valahian Journal of Economic Studies, 10(24).

Mankiw, N. G., Romer, D., \& Weil, D. N. (1992). A contribution to the empirics of economic growth. The Quarterly Journal of Economics, 107(2), 407-437. 
Review of Economics and Development Studies, Vol. 7 (2) 2021, 205-213

Mincer, J. (1958). Investment in human capital and personal income distribution. Journal of Political Economy, 66(4), 281-302.

Mushkin.S.J.(1962). Health as an Investment. Journal of Political Economy, 70, 129-57.

Ogundari, K., \& Awokuse, T. (2018). Human capital contribution to economic growth in SubSaharan Africa: does health status matter more than education?. Economic Analysis and Policy, 58, 131-140.

Osoba, A. M., \& Tella, S. A. (2017). Human capital variables and economic growth in Nigeria: An interactive effect. EuroEconomic, 36(1).

Pesaran, M. H., Shin, Y., \& Smith, R. J. (2001). Bounds testing approaches to the analysis of level relationships. Journal of Applied Econometrics, 16(3), 289-326.

Renelt, D., and Levine, R. (1992), A sensitivity analysis of regressions. American Economic Review, 82, 942-963.

Romer, P. M. (1994). The Origins of Endogenous Growth, Journal of Economic perspectives, 8 (1), 3-22.

Schultz,T.W. (1961). Investment in human capital. The American Economic Review, 51(1), 1-17.

Seebens, H., \& Wobst, P. (2003). The impact of increased school enrollment on economic growth in Tanzania. Bonn: Center for Development Research.

Sequeira, T. N. (2007). Human capital composition, growth and development: an R \& D growth model versus data. Empirical Economics, 32(1), 41.

Solow, R. M. (1956). A contribution to the theory of economic growth. The quarterly journal of economics, 70(1), 65-94. 